\title{
Inculcated Values by Parents to Early Children
}

\author{
Nur Cholimah ${ }^{1}$, Rita Eka Izzaty ${ }^{2}$, Budi Astuti ${ }^{3}$ \\ ${ }^{1}$ Universitas Negeri YogyakartaIndonesia \\ Correspondences: nurcholimah@uny.ac.id; rita_ekaizzaty@uny.ac.id; budi_astuti@uny.ac.id
}

\begin{abstract}
Value education on early children is one of important priorities to shape children's strong character and personality. Therefore, this research is aimed at exploring inculcated values by parents to early children. The respondents of this survey research were 45 parents who had children age 4-6. The research was conducted in An-Nuur Early Childhood Education Program, Krapyak, Sleman, Yogyakarta. To collect the data, this research employed open questionnaire. The respondents (parents) were asked to choose values expected and taught to children. On the instrument, there were 10 important values to choose by the respondents. They were: honesty, comity, manners, discipline, independence, respecting others' right, modesty, social responsibility, empathy, and bravery. Furthermore, the parents were asked to write down unwritten values on the questionnaire. Then, the respondents were asked to rank the values based on the priority of shaping children's characters. Based on the values ranked by parents, the are 4 categories of values taught to children, starting from the most to the least important. They are: 1) honesty, comity, and anners; 2) harmony, discipline, independence, and respecting others; 3) modesty and social responsibility; and 4) empathy, gratitude, bravery, and patience. The instrument is in the form of open questionnaire which consists of various values frequently transmitted by parents to early children.
\end{abstract}

Keywords: values; parents; early children 


\section{INTRODUCTION}

Preschool period is an important stage on human life (Berk, 2012) since on that period, intelligence development increases from $50 \%$ up to $80 \%$. Furthermore, on that period, children begin to be sensitive in receiving various efforts to develop all potential possessed (National Ministry of Education, 2008). This also means that an early age ranging from 0-6 years old is a foundation to shape individual development. Moreover, in preschool years, the foundation of behavior formation through habituation and training should have been taught to children.

Family is a small unit where children are able to learn values and understand the world (Soekanto, 2004). Educating children from early ages is definitely important. Children must get and be familiar with both formal education as well as education which teach values. Educational values relate to children's behavior, either words or action, and the values are shaped through experience and gained from environment through education and nurture (Hasan, 2012). Some scientists predict that giving stimulation in this period will influence children's future development. However, if the children's environment including parents, education, and society gives inappropriate stimulation, they will not probably develop as expected.

Puspitasari and Ardani's (2014) research on the prevalence of emotional problems and preschool children's behavior in Pande, East Denpasar shows that abnormal values of emotion, hyperactivity, aggressive behavior, and peer relationship scales mostly occur on children age 6. Emotion scale has a percentage of $83.3 \%$, hyperactivity is as much as $100 \%$, and peer relationship is as much as $75 \%$. In this age, children start to come to real world, try to perform their responsibility, and are prepared to attend schools. Therefore, it arises emotional and behavioral changes related to their new peers. Moreover, this research explains that emotional and behavioral changes of early children are influenced by family, especially methods of parents' nurture.

The phenomena mentioned above raise empathy. To prepare a qualified human resource, good education must be taught to children from the early period. Children not ony learn formal education, but also education of values which relies on all parties, especially family where children learn to acknowledge world for the first time. Therefore, family as well as educational institutions have similarly important roles in giving children appropriate stimulations and guidance to create qualified generations. Parents expect that their children have soft character and are accepted in the society. Therefore, parents expect that family 
environment or schools can teach positive values or local wisdom values which enable children to grow, develop, and be accepted by society.

From the previous explanation, it can be concluded that early children period is a fundamental of children's future development. Children were born to be holy and they are the God's madate to parents. Furthermore, children were born innocent with pure heart and mind and thus, parents receive the God's blessing with their existance. It is no wonder that parents and society are fully responsible for children's good development. As the result, they will be a useful creature for themselves, family, society, nation, and religion based on the God's (Alláh) rules.

\section{METHOD}

This research employed survey research model. The research respondents in the beginning step (survey) were 45 parents who had children age 4-6. This step was aimed to examine values taught by parents. This research in An-Nuur Early Childhood Education Program, Krapyak, Sleman, Yogyakarta. Meanwhile, to collect the data, this research employed an open questionnaire. The respondents (parents) were asked to choose the values expected/taught to children. Then, they were asked to rank those values based on the priority which shapes children's character.

\section{FINDINGS}

The 45 respondents who filled in the instrument show 10 important values to develop. They are: honesty, comity, manners, discipline, independence, respecting others' right, modesty, social responsibility, empathy, and bravery. Meanwhile, based on the ranks of recommended values for children, there are 4 categories of values starting from the most to the least important. They are 1) honesty, comity, manners, 2) harmony, discipline, independence, repecting others' right, 3) modesty, social responsibility, and 4) empathy, gratitude, bravery, and patience. The instrument used was in the form of open questionaire which consists of values frequently taught by parents to early children. The questionaire gives parents chance to write down not mentioned values.

\section{DISCUSSION}

Values are important parts of experience influencing individual behavior. Through values, an individual has a guidance to behave, think, live, and interact with others (Eyre \& Eyre, 1993). Having good values is expected to bring someone to better life. Therefore, education of values must be taught to early children. Teaching character values to early childhood is the responsible of all parties including family, teachers, and society. Family as a small-social unit is the primary and initial education environment for children (Soekanto, 
2004). This shows that a family is the most responsible environment which educates children. Furthermore, parents must teach fundamental of education, socialization procecss, and children's life in society.

The family's contribution through parenting is amied at guiding and maturing children. Each parent has different parenting orientation based on their culture and era (Andayani dan Koentjoro, 2004). Characteristics of individual life are influenced by dominant culture of the surrounding (Idrus, 2012). Appropriate parenting will influence chidlren's future life. Furthermore, giving appropriate education, affection, and parenting will influence children's character. Parents' role in parenting is giving fundamental of education, attitude, basic skills of religious education, character, manners, affection, sense of comfort, rule subservience, and habit inculcation. In addition, a family also has roles in teaching children values and behavior accepted by society.

Some general values taught by parents to children are moral value, spritual development, social-cultural values, character education (Halstead \&Taylor, 2000). The research finding shows that some values of local wisdom taught by parents are honesty, respect, manners, discipline, independence, respecting others' right, modesty, social responsibility, and empathy. Those values are considered important and expected to be taught. Furthermore, the values are the manifestation of parents' hope toward children's behavior and profile. Thus, those values are taught with the hope that children can have socially accepted character.

To have socially accepted behavior and moral values, an individual must be able to differentiate goodness and badness. Honesty value is crucially taught to children and trained since the early age. Honesty is an effort to be a reliable individual (Fadillah\& Khorida, 2014). Honesty is not created by itself. To be an honest person, someone needs a lot of daily exercises and habituation.

Besides teaching honesty value, parents also teach the discipline and independence values. Acording to Alwi in Indonesian Dictionary (2002), discipline has three meanings: rules and regulation, obedience, and subjects. It can be interpreted that rules and regulation are regulations to obey or in other words, discipiline is an action showing orderly and obedient behavior to any stipulations and regulations. Discipline strongly relates to rules, laws, or society custom. Therefore, discipline is not seperated from society culture. As a member of society, a child is also taught discipline value from his early period. And thus, he will be accpeted in the society.

Discipline also relates to life value and quality in future period (adulthood). Therefore, discipline must be trained and habituated to make it as a human need (Marijan, 2012). The 
goal of teaching discipline in early children is to create children's good character and accepted behavior based on social and cultural values of children's environment (Aulina, 2013). From the early period, parents need to teach chidlren discipline on managing meal, time, studying, and worshipping. Parents or teachers are expected to explain benefits of discipline for children before they ask children to work in discipline. This will make the children understand the purpose of being discipline. Finally, appliying discipline will bring positive benefits for chidlren's development. According to Schaefer (in Aulina, 2013), discipline includes teaching, guidance, and encouragement performed by adult in order to help children learn live as a social creature and to achieve children's optimal development. Applying discipline in all aspects of life is to make children have self-control. It means that early children are able to control themselves to perform good action and prevent bad action. Discipline is a process which must be performed and habituated all the time. Thus, discipline must be continually performed. Besides, parents should not force children in teaching discipline, but they must habituate it in childrens' daily activities. As the result, children will perform discipline with high awareness instead of force. Furthermore, chilren will completely undestand that the purpose of discipline is to create children's better life and happiness.

Another important value that parents must teach is independence. Parents boast to an independent child. According to Indonesian Dictionary (2012), independence means a situation in which a person stands by himself and is not dependent on others. Independence behavior formed from early period makes children indpendent from parents and automatically raises children's confidence. Thus, children can make their own decision. Independence does not rise by itself. It needs a lot of exercises and continuous train. Children who are not trained to be independent from the early age will be highly depedent on others and less responsible untill they grow up. Therefore, parents crucially teach independence to early children.

Early children must also be responsible for what have been done. Similar to other values, responsibility value does not rise by itself. It must be continually trained and performed. Early childhood is considered as a golden period for teaching good values because in this period children quickly comprehend values and habituate them (Mutiah, 2010). Therefore, parents must be sensitive in teaching good values to children. Parents are not supposed to perform bad action because children will probably imitate it.

Children's responsible behavior can be taught through simple activities. For example, children must be responsible for tidying up their bedroom before doing another activity in the morning, or they must be responsible for tidying their toys and putting them back. 
Responsibility must be taught since early period because it helps children learn self-responsibility and raises environmental awareness.

As a social individual, children are not seperated from society and others' help. Thus, they must be taught to have social behavior and social awareness. As a social individual, chidlren need others' help directly or indirectly. If they do not have social awareness, they will not receive society's awareness. Furthermore, children must also be taught cultural values of the society, such as manners.

Cultural value is also importantly acquainted and habituated to early children. Magnis and Suseno (1999) explain that cultural value taught to early children is harmony attitude to keep the society harmonious. Harmony means calmness and peace without disagreement and conflicts. Meanwhile, the purpose of comity is to manage social interaction patterns with others, including the way to speak, behave, interact, and respect. Comity includes rescpecting self, others, and living things.

Cultural values which are considered important to teach are constructed in the form of hopes toward children's behavior. The values frequently socialized by parents to children are: (a) diligent worship, with the hope that children will be pious, responsible, and tolerant; (b) honesty, with the hope that it will bring advantages and dishonesty will bring disadvantages; (c) comity to elder, with the hope that children are willing to help others, respect others disregarding their social status, and stay humble; (d) being harmonious with relatives and society, with the hope that children will have sensitivity and are willing to give assistance in the form of energy, time, or material, then the they will be accustomed to share, budge, help others, and prevent conflicts; and (e) learning achievement, with the hope that children will diligently attend the school and study, then their learning process and behavior will intensively be monitored at home as well as school (Lestari 2013).

In Islam, a child has vertical relationship with his God and horizontal relationship with his parents and society. The relationships educate children to be responsible.Through good parenting and education, a child will become a good character as his nature. However, misleading parenting and education will create a child with bad character which is inappropriate with Islamic norms.

A child as the God's mandate forms 3 dimensions of relationship in which parents are the central. The first relationship is among parents and the God which is caused children existence. The second relationship is between a child (who still needs guidance) and the God through his parents. The third relationship is among a child and parents under the guidance and rules of the God. In performing the God's precious mandate, in the form of child, parents 
must put Islamic rules as the base of educating and guiding their child. Therefore, he will be a pious person who always takes ways wanted by the God and have a strong character to face the world. Educating children as a pious, civilized, and Islamic human is aimed at maintaining the nature of human who keeps religious values and rules. A child has two potentials either to be good or bad. Therefore, parents are obligated to guide him based on Islamic guidance in order that the child can worship and interact with the God correctly. Children must get good and correct nurture, guidance, and education and thus, they will have good characters, and finally, they will become pious teenagers, adult, and parents. As the result, children as the next generation of the country will grow and develop based on the parents' expectation and the God's rules. Peaceful, happy, and harmonious family life is good for all humans and it is basic human need.

\section{CONCLUSION}

Human success is determined not only by intelectual intelligence, but also by well emitional, social, and spiritual intelligence. Some values taught by parents to children are honesty, comity, manners, discipline, independence, respecting others' right, modesty, social responsibility, and empathy. Education of values is importantly taught to early children because creating a good character takes a long process.

Teaching positive values to children is not merely in the form of oral teaching, but also in the form of training and early habituation. As the consequnce, children will apply in their life. Acquanting and teaching values in early period can be children's guidance in the future. The hopes of parents in An-Nuur Early Childhood Education Prgram/Kindergarten are in line with the Noble Qurán and Hadith. They believe that good and Islamic moral is the most important aspect in creating future generation. 
INCULCATED VALUES BY PARENTS TO EARLY CHILDREN

\section{REFERENCES}

Andayani, B. \& Koentjoro. (2004). Psikologi Keluarga. Peran Ayah Menuju Coparenting. Yogyakarta: Citra Media.

Berk, L. E. (2012). Development Through Lifespan; Dari Prenatal sampai Remaja (Edisi Kelima). Yogyakarta : Pustaka Pelajar

Choirun Nisak Aulina. (2013). Penanaman Disiplin Pada Anak Usia Dini.

Depdiknas. (2008). Penataan Pendidikan Profesional Konselor dan Layanan Bimbingan dan Konseling dalam Jalur Pendidikan Formal. Jakarta: Departemen Pendidikan Nasional.

Eyre, Linda \& Eyre, Richard. (1993). Teaching Your Children Values. New York: Rockefeller Center.

Franz Magnis-Suseno. (1999). Etika Jawa. Sebuah Analisis Falsafi tentang Kebijaksanaan Hidup Jawa. Jakarta: PT Gramedia Pustaka Utama.

Halstead, J. Mark \& Taylor, Monica J. (2000). Learning and Teaching about Values: a review of recent research. Cambridge Journal of education, Vol. 30, No. 2, 2000.

Hasan Alwi, dkk. (2002). Kamus Besar Bahasa Indonesia, Edisi ke tiga. Jakarta: Balai Pustaka.

Imam Musbikin, (2003). Mendidik Anak la Shinchan. Yogyakarta: Mitra Pustaka.

Luh Gede Meilia Puspita Sari \& Iga indah Ardani. (2014). Prevalensi Masalah Emosi dan Perilaku pada Anak Prasekolah di Dusun Pande Kecamatan Denpasar Timur. Jurnal Medika Udayana, Vol 3, No 11, 2014.

Maimunah Hasan. (2012). Pendidikan Anak Usia Dini. Yogyakarta: DIVA Press

Marijan. (2012). Metode Pendidikan Anak. Yogyakarta: Sabda Media.

Muhammad Fadillah dan Lilif Mualifatu Khorida. (2014). Pendidikan Karakter Anak Usia Dini. Yogyakarta: Ar-ruzz Media.

Muhammad Faudzil Adzim (2015). Positive Parenting. Yogyakarta: Pro-U Media

Muhammad Idrus. (2012). Pendidikan Karakter pada Keluarga Jawa. Jurnal Pendidikan Karakter Tahun II, No 2, Juni 2012.

Soerjono Soekanto. (2004). Sosiologi Keluarga. Jakarta: PT Rineka Cipta.

Sri Lestari. (2013). Psikologi Keluarga. Penanaman Nilai dan Penanganan Konflik dalam Keluarga. Jakarta: Kencana Prenada Media Group. 